\title{
THE REGULATION OF ENGLISH MIDWIVES IN THE EIGHTEENTH AND NINETEENTH CENTURIES*
}

\author{
by
}

THOMAS R. FORBES

IN ENGLAND in the seventeenth century nearly all babies were delivered by midwives. These women were licensed not by civil authority but by the Church. The texts of licences granted to midwives in London beginning in 1661 include statements that the women were of good character and experienced in their profession. Often it was also stated that they belonged or conformed to the Church of England. Usually a licence carried the names of a half-dozen or more neighbours, friends, and clients who testified to the competence and 'good \& honest life and Conversation' (behaviour) of the midwife. The document was submitted by the applicant to the surrogate representing the bishop or his chancellor. If all was in order, the official administered an oath of office to the midwife and the licence was granted. ${ }^{30,81}$

Obviously such a procedure provided less than adequate control of the practice of midwifery. The licence supplied only lay evaluation of professional competence. Since the parchment was supposed to be granted only to experienced midwives, beginners could not be licensed. Possession of a licence must have helped a midwife to attract clients, but it is likely that because of the expense and trouble involved many midwives never got around to seeking licensure. Not all of them would recognize the authority of the Church, and in any case the jurisdiction of an ecclesiastical court in regard to the midwife's licence was open to question. $28,30,31$ Nevertheless, the licensure system clearly was useful. One might expect that from it there would have evolved, over the course of a few decades, a formal and enforceable requirement for the training, examination, and registration of midwives. The Royal College of Physicians of London had been founded in 1518; The Company of Barber-Surgeons, in 1540; The Worshipful Society of Apothecaries, in 1617. Each of these bodies controlled the standards for the admission and the professional conduct of its members. It is therefore surprising to learn that the regulation of midwives did not become the law of the land until the Midwives Act was passed in 1902.12 A gestation period of more than two centuries deserves our examination.

Licensure of midwives by the Church continued well into the Georgian period, although the practice must have been waning. There is on record a brief notice of a 'licence from Henry Squire, Commissary of the Dean and Chapter of York, to Jane Palmer, of Pidsey, for practising the office of midwife, dated 1716, signed and sealed. ${ }^{56}$ The text of another licence, ${ }^{14}$ translated from the Latin, reads:

Lucas Cotes, Clerk, Master of Arts, Dean of the Collegiate Congregation of Middleham, lawfully appointed, to all the faithful in Christ to whom this present writing shall come, greetings. We desire it known that by reason of her skill, knowledge, and industry among women

- This research was supported by grant 1 RO1 LM 00570 from the U.S. Public Health Service. 


\section{The Regulation of English Midwives in the 18th and 19th Centuries}

in grave peril at the time of childbirth, we therefore admit Mary Stott, wife of Thomas Stott of the aforesaid Middleham, appearing before us through a certificate in her behalf under the hand of certain matrons, to the exercise and practice of her art or profession of midwife in and throughout all the said deanery of Middleham, insofar as it shall have been requested and necessary, and as much as is in us and we are able under law we give and concede to the same Mary Stott licence and free power from this time for as long as she shall have conducted herself properly and shall put herself in our charge. Given under our seal of office (which we use in such matters) the six and twentieth day of August in the year of our Lord 1721.

John Waite, Notary Public

L. U. Cotes (seal), Dean of Middleham

Aveling gives the text of a licence granted in $1738 .{ }^{18}$ In the Diocese of Norwich thirty individuals were authorized between 1770 and 1786 'to perform the office, business, and functions of midwife', but no later licences were granted in that diocese. ${ }^{19}$ I have not learned of episcopal licences issued after this time, although bishops of the Church of England, employing the criteria of recommendation 'under the hands of matrons, who have experienced her skill, and also of the parish minister, certifying as to her life and conversation, and that she is a member of the Church of England', could still license a midwife as late as 1873, just as the Archbishop of Canterbury could grant medical and other degrees. ${ }^{43}$

It is not entirely clear why the conferring of licences by the Church waned. Atkinson suggests that the emergence of the 'male midwife' was a factor. ${ }^{18}$ Certainly, as we shall see, this development created problems. Also, it was claimed, the bishops were not sufficiently rigorous in selecting midwives for licensure. Richard Tyson, M.D., physician to St. Bartholomew's Hospital, in An address . . . to the College of Physicians, and to the Universities of Oxford and Cambridge; occasion'd by the late Swarms of Scotch and Leyden Physicians, \&c. Who have openly assum'd the Liberty (unlicens'd from the College, \&c.) of practicing Physick in England . .., complained of

another Hardship on the fair Practitioner, which loudly demands the Attention of the B-ps [Bishops]; I mean, their licensing various Persons in their respective Dioceses. The Origin of that Custom might probably be in the Days of Popery, of which 'tis a Relict, and the B-p might then be a proper Person to License, when the Practitioners both in Physick and Midwifery were chiefly Monks.

Another physician, Henry Bracken, made it clear in the Preface of The Midwife's Companion; or, a Treatise of Midwifery that the bishop's licence was no guarantee of the competence of the midwife.

And, indeed, some People are so ignorant, that they imagine, if the Midwife only bring the Child into the World, either Whole or Piece-meal, she performs a dexterous Work; it is well therefore in the World for such Butcherly Midwives, that the Child (though it happens to be born alive) cannot give an Account what Usage it has met with in the Birth. But let them consider, a Day will come when such Actings will be judged little less than Murder in plain Daylight: And I wonder that there is not (for the Preservation of the Lives of many of his Majesty's Subjects) a Law, to have a Jury appointed, with the Assistance of an able and honest ManMidwife, to enquire into the Circumstances of the Case of Children born dead, maimed, or distorted: But so far from this, that the Law is such at present, That a Woman who can only procure the Hands of a few good natur'd Ladies, or Justices of the Peace, to recommend her to the Bishop or Ordinary, shall have a license to Practice, although neither those who recommended, nor the Bishop himself know anything of the matter ...20 


\section{Thomas $R$. Forbes}

As the episcopal licensure of midwives became infrequent, the standards of the midwife sank even lower than they had been in past centuries. Dreadful stories were reported on good authority of mutilation and death caused by ignorant midwives. ${ }^{15,18}$ T. Dawkes, a surgeon, stated that rural 'Midwives are so very ill-qualified for their Office, that not one in ten of them, can give a judicious Practitioner, such an Account of any Case they are concerned in, as will afford him the most slender Satisfaction.'28 Another surgeon who also practiced midwifery asserted that

it is a Truth too well known, that Mothers and their Children are daily, if not hourly destroyed [such is the Practice of Midwifry in our Days] by ignorant Wretches, in almost every State of Life, a Pack of young Boys, and old superannuated Washer-women, who are so impudent and so inhuman as to take upon them to practise, even in the most difficult Cases, which can possibly occur.

How much then, is it to be lamented that no Care has yet been taken by any Law, to prevent these cruel and most fatal Proceedings! ${ }^{25}$

Worried obstetricians tried to stem the tide. They described at length the qualities that a good midwife should possess-youth, health, literacy, intelligence, knowledge, energy, sobriety, resolution, patience, and so on. ${ }^{18,27,40}$ The profession undoubtedly attracted some women of this type, but evidence is lacking that they were the rule. A few London physicians also offered courses of instruction for midwives. John Mawbray in 1724 advertised such a course in his house in New Bond Street, and in 1739 Sir Richard Manningham taught midwifery to 'physicians, surgeons, and women' at a small lying-in hospital. ${ }^{18,42}$ Instructors in midwifery multiplied in the eighteenth century, but not all of them would teach women. By 1800 the profession had sunk into a 'state of anarchy'.13

Most babies were still being delivered by women at this time, ${ }^{33}$ although the "male midwife' had emerged in England in the seventeenth century.* Henrietta Maria, consort of Charles I, had been attended by Peter Chamberlen in 1628 during a miscarriage, and Hugh Chamberlen was accoucheur to the future Queen Anne in 1692.32 The secret of the obstetrical forceps, at first a monopoly of the Chamberlen family, was revealed in the $1730 \mathrm{~s}^{52}$ Before long the instrument was used by many male midwives but not by their feminine counterparts, either then ${ }^{37}$ or much later. ${ }^{3}$ The popularity and male monopoly of this instrument contributed to the increasing appearance of men in delivery rooms. In 1754 Benjamin Pugh could comment that 'every young Surgeon now intends practicing Midwifery, and it is become almost as universal amongst Men in this Kingdom, as ever it was in France'. ${ }^{45}$ It is believed that by that time there were some hundreds of male midwives in London alone. ${ }^{23}$ By the latter part of the eighteenth century many well-to-do families were employing accoucheurs. The poor could not afford them. ${ }^{2,13,38}$

The threat of male competition, and of ultimate male control, was vigorously

* One of the many problems created when men entered the profession was what to call them. Such terms as male-midwife, midman, man-midwife, physician man-midwife and androboethogynist ${ }^{2,41,52}$ were clumsy and ridiculous. Accoucheur was better but not English. Fortunately Michael Ryan in 1828 offered a sensible solution in his Manual on Midwifery: "As there is no exact term in the English language expressive of the male practitioner of midwifery, except the French word accoucheur, I propose the word Obstetrician, which is as appropriate as electrician, geometrician, \&c. Custom will soon render this term as familiar as accoucheur; and none can deny but it is more national.' 17 


\section{The Regulation of English Midwives in the 18th and 19th Centuries}

countered by the midwives. During the eighteenth and much of the nineteenth century use of the obstetrical forceps, man-midwifery in general, and prominent male practitioners of the art in particular, including the distinguished William Smellie, were bitterly attacked by such midwives as Mrs. Elizabeth Nihell, Mrs. Elizabeth Cellier, and Mrs. Sarah Stone and, curiously, by some male doctors, among them Frank Nicholls and William Douglas, whose sense of propriety was outraged at the thought of a man examining a pregnant woman or attending her delivery. $18,41,44,50,52,54$ On occasion there were personal quarrels, ${ }^{40}$ and editorials in the press were scarcely less vehement. ${ }^{2,3,4}$

Throughout the nineteenth century most babies were born at home, and most of these were delivered by midwives. ${ }^{8,12,15,38}$ The position of the midwife even in the face of rising medical opposition continued to be strong. Preference for her services apparently was due to tradition, to her greater availability, particularly in small communities and rural areas, and to financial necessity. In 1872 the obstetrician's fee was reported to be from one-half to two guineas. ${ }^{2}$

The total count of midwives in Victorian England is uncertain.

$\begin{array}{rrl}1873 & 10,000 & \text { (Estimated by expert) } \\ 1881 & 2,646 & \text { (Census) } \\ 1901 & 3,055 & \text { (Census) } \\ 1907 & 24,500 & \text { (Midwives Roll) }\end{array}$

It was thought that of the last group, two-thirds were actually in practice.,13,15,17 In 1873 there were reported to be 150 midwives in London. ${ }^{3}$ The number of deliveries by midwives in England in 1902 was estimated to be about $450,000 .^{11}$

Yet under the existing system the training of the midwife, through no fault of her own, continued to be seriously deficient. $5,91,6,17,35,38$ A deputation from the Parliamentary Bills Committee of the British Medical Association stated on 4 April 1873 that in general midwives commenced their business on no more experience than that of having themselves been mothers, or of having attended one or two labours.'5

Between 1857 and 1874 training courses for midwives were started at four lying-in or general hospitals in London. A Manchester doctor in 1820 had given a course of lectures to midwives and granted a certificate. But most such 'licences' from individuals were unofficial, misleading and dangerous. One of these dubious documents even had the royal arms printed at the top. No law prevented the distribution of the 'licences' and no official register of licensed midwives was kept.8,13 Any woman was free under the law to identify herself as a midwife ${ }^{15}$ and to practise that profession, although she could not legally in her capacity as midwife treat diseases related to childbirth. ${ }^{8,11,48,57}$

An article in the Medical Times and Gazette for 15 June 1872 reported, 'The mortality in childbed is now throughout England and Wales estimated by Dr. Farr [William Farr, the statistician] as 1 in 189-that is, about one-third of what it was in the middle of the seventeenth century, when the practice was in the hands of midwives.' Inasmuch as the practice was still largely in their hands, the argument seems to support a point of view opposite to what the author intended. A mortality rate of 1 in 189 is equivalent to about 5.3 per thousand. This was close to an estimate in $1873^{5}$ that the 'mortality from childbed in all England was 1 in $200 \ldots$. The report 


\section{Thomas R. Forbes}

went on to say that in the Royal Maternity Charity Hospital, an institution in which only trained midwives were employed, the maternal death rate in childbed was 'in general 1 in 400, and last year 1 in 900'. In parliamentary debate on the Midwives Bill in 1902 (see below) it was stated that in 13,712 deliveries taking place in large institutions and hospitals and attended only by trained midwives there were only 17 maternal deaths (a rate of 1.23 per thousand), as compared to a rate for England as a whole of 4.66.11

The President of the Obstetrical Society of London testified on 21 November 1873 before the Right Honourable James Stansfeld, M.P.:

Not only is there a great excess of mortality among parturient women, and a greater number of still-born children than there should, but there is a great deal of preventible disease among women in parturition, which is caused by the incompetence of their attendants. If some of these poor women escape with their lives, they are often not able afterwards to do a day's work, many of them being permanently invalided, their homes broken up, and their children thrown upon the parish. I believe the expenditure entailed in this way upon the country is certainly far greater than any sum of money which it might be necessary for Government to spend in setting the instruction and licensing of midwives on a reasonable footing.

On 8 December of the same year a deputation of midwives, some of them members of the Obstetrical Association of Accoucheuses, waited on Mr. Stansfeld. ${ }^{3}$ This group of ladies agreed with their predecessors about 'the present unsatisfactory professional condition of the large class of women working in every part of the United Kingdom as midwives', urged reforms in training and licensure, and presented statistics confirming that well-trained members of the profession could deliver women in relative safety. The mortality rate in childbirth, it was stated, was 1 in 190 in Great Britain as a whole.

At the Dublin Lying-in Hospital, under medical men, 1 in 132.

British Lying-in Hospital, where doctors are called in when a difficulty occurs, 1 in 338-1/4.

Patients attended by Mrs. Salter, 1 in 1,000.

Patients attended by Manchester midwives, 1 in 750.

Royal Maternity Charity, average for 10 years, 1 in 534 cases.

In 1872 the midwives of the Royal Maternity Charity attended 3,666 cases with but 4 deaths.

It was becoming ever more clear that reforms in the training and regulation of the midwife were imperative. But serious deficiencies continued to occur., ${ }^{71,29.39}$ Some shocking cases were due to ignorant and untrained male 'irregular practitioners'. One of them 'had just taken up the practice of midwifery, and the only instruction he had received in the art was from an old midwife in the neighbourhood'. At one delivery he mistook the presenting head for the placenta. In attempting to cut through this structure, which he believed was responsible for the difficult labour, he scalped the baby. The surgeon who reported this case ${ }^{29}$ and a physician ${ }^{35}$ related numerous others that were worse, all the work of accoucheurs totally lacking in training.

At about the same time another male midwife was indicted for the murder of a woman he had delivered; he had also been charged by the coroner with manslaughter. ${ }^{21}$

The prisoner was about seventy-five years of age. He was not a regularly educated accoucheur, 


\section{The Regulation of English Midwives in the 18th and 19th Centuries}

but a person who had been in the habit of acting as a man-midwife among the lower classes of people. Following the delivery there was a prolapse of the uterus. The prisoner, mistaking the protruding part of the organ for a persistent portion of placenta, tried to remove it by force. The mesenteric artery was ruptured, and the patient died.

The trial was held at the Old Bailey (Rex v. Williamson, O.B. 1807). Lord Ellenborough, Chief Justice, in summing up, stated that the prisoner 'was not indictable for manslaughter, unless he was guilty of criminal misconduct, arising either from the grossest ignorance or the most criminal inattention.' Since the prisoner, on the testimony of numerous female witnesses for the defence, had delivered them successfully, it was argued that he 'must have had some degree of skill'. Also, it 'does not appear that in this case there was any want of attention on his part'. The Chief Justice concluded,

I own, that it appears to me, that if you find the prisoner guilty of manslaughter, it will tend to encompass a most important and anxious profession with such dangers as would deter reflecting men from entering it.

Verdict-Not guilty.

Liverpool coroners, it was alleged in $1831,{ }^{55}$ 'do refuse, and have invariably, I understand, refused to notice the delinquencies of midwives in the lying-in room, upon the plea of having no legal authority to notice them.' Even in 1901 the legal position in England still was, briefly, that

any person who chooses may undertake the important duties of midwife. No test of competency for the office is imposed by any responsible authority and so the public are left to such protection as the common law affords against the malpraxis of uninstructed practitioners .... In the case of one undertaking the office of a midwife, as in that of a registered medical practitioner, the law implies not that she will bring her patient safely through the perils of childbirth, but that she will use reasonable professional skill and due diligence to that end. ${ }^{10}$

Medical students wishing to qualify for registration were obliged under the Medical Act of 1886 to pass an examination in midwifery, but that Act, like the Medical Act of 1858 , did not apply to midwives. ${ }^{10,37}$

Although the legal regulation of the training, examination, licensure, and registration of midwives was long delayed, repeated efforts were being made by individuals and professional bodies to initiate reform. George Counsell had urged in The Art of Midwifry, published in 1752, that the Royal College of Physicians be legally empowered 'to appoint annually one or more of their Members, eminent in the Profession of Midwifry, to examine and licence all Persons, Men as well as Women', who wished to practise in the jurisdiction of the College, that is, in London and within seven miles of its boundaries. ${ }^{25}$ The College did in fact receive this power at about this time, not relinquishing the responsibility until the 1820 s. $^{10,13}$ Thomas Denman and William Osborn became in 1783 the first licentiates of the College. Only eight others, all men, were licensed..$^{52}$ Because the College so seldom exercised its right of licensure, the Society of Apothecaries in 1813 felt obliged to petition Parliament to set up a system for the examination and licensure of midwives. The petition was denied. ${ }^{15,18,23,34,37,38,54}$ Subsequently, the Society decided that applicants for its medical degree must take an examination in midwifery in addition to other 
subjects. In 1817 the College of Physicians expressed the opinion that the delivery of infants was the province of the surgeon while women's diseases was that of the physician. ${ }^{23}$

Dr. Thomas Denman, licentiate of this College, and other obstetricians pleaded unsuccessfully with the College of Surgeons in 1808 to establish a diploma in midwifery. Urged again in 1826 and 1827 by the newly-organized and short-lived Obstetrical Society, the College pointed out a technicality-surgeons experienced in obstetrics were barred from its Court of Examiners. ${ }^{24}$ Matters dragged on. In 1833 the College was empowered through a supplementary charter to examine candidates for a diploma in midwifery. ${ }^{18,88}$ In 1847 the National Institute of Medicine, Surgery, and Midwifery, founded two years earlier, petitioned the government for a royal charter to incorporate general practitioners into a college. ${ }^{1,18}$ The Poor Law Commissioners in 1851 added qualification in midwifery to the other requirements for their medical officers. ${ }^{13.54}$ Finally, in 1852 the College of Surgeons set up a Midwifery Board consisting of three obstetricians and a vice-president of the College. Applicants for its diploma in midwifery were expected to attend two lectures in the subject, deliver twenty babies, and pass the examination of the Board. Thirty-one candidates were successful as of January $1853 .{ }^{15,24,37}$

The second half of the nineteenth century saw a confusing succession of efforts to bring about regulation of midwives. The story has been told by Atkinson ${ }^{18}$ and others, and need only be summarized here. As early as 1788 a Dr. Ramsbotham and other men practising midwifery had attempted to start a society intended to improve the political position of their colleagues and of midwives. The Obstetric Society was founded in 1825 as a result. It was succeeded in 1858 by the London Obstetric Society. At its first meeting in 1859 obligatory training and an optional examination for midwives were proposed. ${ }^{37}$ The preamble of the Medical Act of 1858 had stated: 'It is expedient that persons requiring medical aid should be enabled to distinguish qualified from unqualified practitioners.' Interested persons promptly claimed that this statement applied to midwives. ${ }^{13}$

In 1826 the Female Medical Society was organized 'to provide educated women with proper facilities for learning the theory and practice of Midwifery, and the accessory branches of medical science.'13 Humphreys has pointed out that among its requirements this Society included examinations in the diseases of women and children as well as in midwifery, thereby confusing two very different kinds of training and responsibility and attempting to give midwives equal status with physicians and surgeons. ${ }^{36}$ We hear nothing more of the organization.

In 1869 Dr. William Farr (see above), Superintendent of the Statistical Department in the Registrar General's Office, suggested a broad investigation of the reasons for infant mortality. This study was undertaken by a committee of the London Obstetrical Society. Its report in 1870 showed that in England midwives delivered 50 to 90 per cent of the babies of the poor, that the midwives had almost no training, and that there were appalling numbers of stillbirths and maternal deaths. The report induced the Society in 1872 to establish an examination for midwives and to award certificates of competence, a practice that continued for thirty years, $3,18,15,26,34,37,54$ although the original proposal to certify qualified midwives was bitterly opposed both by a seg- 


\section{The Regulation of English Midwives in the 18th and 19th Centuries}

ment of the medical profession and by the Obstetrical Society of Accoucheuses and other London midwives. ${ }^{2,4,16}$ The midwives objected in part because, they said, the certificate would permit their attendance only at 'natural' (i.e., uncomplicated) labours. ${ }^{3}$

The London Obstetrical Society and the British Medical Association formed a joint committee which in 1873 proposed Parliamentary reforms in the midwife situation. However, the next year there was a change of government and various sympathetic M.P.s including Mr. James Stansfeld (see above) were replaced. ${ }^{17,37,54}$ At this time the Society had about 600 Fellows. $^{3}$ By 1891 it had licensed 918 midwives, ${ }^{66}$ and its certificate, although lacking legal basis, had acquired much respect. ${ }^{38}$

Florence Nightingale in 1872 published a plan for training midwives and stated that the necessary instruction would require two years. ${ }^{13}$ Miss Nightingale looked on midwifery as a branch of nursing. ${ }^{54}$

The Ladies Obstetrical College, located in Great Portland Street, was founded in 1873 '1. To establish an Obstetrical College for educated women. 2. To obtain such amendment of the Medical Acts as will give women access to a registrable diploma for the practice of midwifery, and confer upon properly educated midwives a defined professional status.' ${ }^{13,15}$

On 20 December 1872 the Council of the Obstetrical Association of Midwives in a letter to the Council of the Royal College of Surgeons of England had requested that an examination in midwifery be conducted and that a licence or certificate in that subject be granted. ${ }^{3}$ In 1875 three ladies sought to take the College's examination in midwifery. ${ }^{13}$ The Russell Gurney Enabling Act, passed in the same year, permitted women to be admitted to examination by professional bodies. The Council of Examiners of the College, however, was of the opinion that all persons practising midwifery should also be well grounded in general medicine. The Council therefore refused to permit the examination requested by the ladies. The Midwifery Board of Examiners resigned in protest in January 1876. The Obstetrical Society of London supported the Board's protest. ${ }^{3,13,15,24}$

The General Medical Council had been created by Act of Parliament to regulate preparation for, admission to, and conduct within the medical profession. ${ }^{23}$ In 1873 the Council requested power 'to register qualifications of women as Midwives'. ${ }^{13}$ In the same year a committee of the Parliamentary Bills Committee of the British Medical Association joined with the Obstetrical Society in preparing a recommendation regarding the education and control of midwives, stating, 'Thousands of women are at present acting as midwives who have received no obstetrical instruction whatsoever.'3,36.37 The recommendation was, as already noted, presented to James Stansfeld, M.P., by a deputation on 4 April 1873, but no legislation resulted. A bill for the registration of midwives in England and Wales was drafted by the Parliamentary Bills Committee as the 'Midwives Act, 1882', ${ }^{\circ}$ but was not passed. The British Medical Association and the London Obstetrical Society continued to draft bills and to bring them to the attention of Parliament, but without significant result. ${ }^{13,54}$

The Midwives Institute, later to become the College of Midwives, was founded by a group of midwives in 1881 and was incorporated in 1889 . Its aim, of course, 


\section{Thomas R. Forbes}

was to improve the competence and status of the profession. All of its members were Licentiates of the Obstetrical Society. The Institute enjoyed the vigorous support of Florence Nightingale. In 1890 it introduced a Midwives Registration Bill into the House of Commons. Although the bill was blocked, the Institute initiated other Parliamentary bills in each succeeding year until 1902, when the Midwives Act was passed. ${ }^{13,34,37,64}$

An Association for the Compulsory Registration of Midwives and a Midwives Registration Association were founded in 1893. Both organizations spread throughout the country and co-operated in the campaign for definitive legislation. ${ }^{13,37,54}$

Pressure on Parliament had been mounting in the last quarter of the nineteenth century. A governmental survey, released in 1875 , of the regulation of midwives on the Continent made it clear that Britain was lagging far behind. ${ }^{13}$ Bills were introduced in Parliament almost every year. Deputations waited on Members and Ministers. Select Committees of the House of Commons in 1892 and 1893 investigated midwifery, expressed alarm at the current situation, and urged reform.7, $9,11,18,37,54$

Finally, on 31 July 1902 there was passed the Midwives Act (2 Edw. 7, ch. 17) 'to secure the better training of midwives, and to regulate their practice'. The law, which came into effect on 1 April 1903, established a Central Midwives Board to supervise the registration and training of midwives throughout England and Wales. It became illegal for unregistered midwives to attend confinements regularly and for gain unless supervised by a doctor. Women already established as midwives when the law was passed were registered if they had certificates of training or had had at least a year of professional experience and were of good character. (Well over half of the midwives so admitted were untrained.) After 1 April 1910 women seeking to become midwives were required to have met a satisfactory level of training, to pass examinations set by the Board, and to adhere to strict rules for professional activity. ${ }^{13,21,34,37,51,54}$

Thus ended a struggle of centuries, a struggle first of all to sweep away unnecessary suffering and loss of life, but also to insure for the midwife the high level of competence and respect appropriate to her calling. Like some other medical and social reforms, this had to be slowly constructed amidst the pressures of professional self interest and militant feminism and the encumbrances of bureaucratic inertia and public ignorance and prejudice. Meanwhile the innocent suffered. But reform finally came, as it always can in a good cause. After all, as Jane Sharp said, 'The art of midwifery is doubtless one of the most useful and necessary of all arts for the being and well-being of mankind. . $\therefore{ }^{49}$

\section{REFERENCES}

1. [ANon.], 'To the Right Honourable Sir George Grey, Baronet, Her Majesty's Principal Secretary of State for the Home Department. The Memorial of the President, VicePresidents, and Council of the National Institute of Medicine, Surgery, and Midwifery', Accounts and Papers, House of Commons, 20 December 1847, 51, 591-93.

2. [ANON.], 'Women midwives', Med. Times Gaz., 1872, 1, 686-87.

3. [ANON.], 'Melioration of midwives. Proceedings of the deputation of the Obstetrical Society of London to the Right Honourable James Stansfeld, M.P.', Obstetl. J.. Gt Brit. Ir., 1873, 1, 617-25, 689-98. 


\section{The Regulation of English Midwives in the 18th and 19th Centuries}

4. [ANON.], 'The education of midwives', Med. Times Gaz., 1873, 2, 608-9.

5. [ANON.], 'The registration of midwives', Brit. med. J., 1873, i, 415-16.

6. [ANON.], 'Registration of midwives in England and Wales draft bill', Brit. med. J., 1883, i, 222-24.

7. [ANON.], 'Report from the Select Committee on Midwives' Registration; Together with the Proceedings of the Committee, Minutes of Evidence, Appendix, and Index', Accounts and Papers, House of Commons, 17 June, 1892, 14, 1-181.

8. [ANON.], 'Still-births in England and Other Countries', Accounts and Papers, House of Commons, 21 June 1893, 73, 335-468.

9. [ANON.], 'Report of the Committee on the Registration of Midwives', Lancet, 1893, ii, 459-60.

10. [ANON.], 'The legal status of midwives', Lancet, 1901, ii, 1301-2.

11. [ANon.], 'The Debate on the Midwives Bill', Lancet, 1902, i, 688-92.

12. [ANON.], Encyclopaedia Britannica, Chicago, 1969, 15, p. 418.

13. AtkInson, S. B., The Office of Midwife . . . , London, Bailliere, Tindall \& Cox, 1907, pp. 14-25.

14. AtTHILL, William, Documents relating to the ... Collegiate Church of Middleham ...., London, John Bowyer Nichols, 1847, pp. 103-4.

15. Aveling, J. H., 'On the instruction, examination, and registration of midwives', Brit. med. J., 1873, i, 308-9.

16. Idem., 'The Obstetrical Society of London and midwives', Brit. med. J., 1874, i, 153-54.

17. Idem., 'Education of midwives', Brit. med. J., 1875, i, 453.

18. Idem., English Midwives . . . , London, Hugh K. Elliott, 1967, pp. 48, 86, 93-95, 100-2, 132-39, 142-44, 152-56, 163-68.

19. Barnes, Henry, 'On the Bishop's Licence', Trans. Cumberland and Westmoreland Antiquarian and Archaeol. Soc., 1903, n.s. 3, 59-69.

20. Bracken, Henry, The Midwife's Companion ... . , London, J. Clarke, 1737, [no pagination].

21. Carrington, F. A., and Payne, J., Reports of Cases Argued and Ruled at Nisi Prius ..., London, S. Sweat, 1829, 3, 635-36.

22. ChampNeYs, F. H., 'Midwives in England, especially in relation to the medical profession', St. Bart.'s Hosp. J., 1907, 15, 24-26, 39-46.

23. Clark, George, A History of the Royal College of Physicians of London, Oxford, Clarendon Press, 1964, 1966, 1, pp. 67, 237; 2, 502, 664, 728.

24. COPE, ZACHARY, The Royal College of Surgeons of England; a History, London, Anthony Blond, 1959, pp. 129-32.

25. Counsell, George, The Art of Midwifry . . . , London, C. Bathurst, 1752, pp. x-xiii.

26. Crombie, C. M., Remarks on Midwifery to Midwives, Aberdeen, John Adam, 1872, pp. 22-23.

27. DaVenter, Henry à, The Art of Midwifery Improv'd . . . , London, A. Bettesworth, W. Innys, and J. Pemberton, 1728, p. 8.

28. Dawkes, T., The Midwife Rightly Instructed . . , London, J. Oswald, 1736, pp. iv-v, ix-xiii.

29. Evans, David, 'A series of cases of bad practice in midwifery and surgery, illustrative of the evils which result from uneducated persons being allowed to practise those branches of the medical profession', Trans. Ass. Apoth. Surg.-Apoth. Engl. Wales, $1823,1,201-7$.

30. Forbes, T. R., 'The regulation of English midwives in the sixteenth and seventeenth centuries', Med. Hist., 1964, 8, 235-44.

31. Idem., The Midwife and the Witch, New Haven, Yale University Press, 1966, pp. 139-55.

32. Garrison, F. H., An Introduction to the History of Medicine . . ., Philadelphia, Saunders, 1929, p. 337.

33. Glaister, John, Dr. William Smellie and His Contemporaries, Glasgow, James Maclehose, 1894, pp. 32, 35. 
34. Gordon, J. E., 'British midwives through the centuries. 3. From the 18 th century to today', Midwife Hlth Visitor, 1967, 3, 275-81.

35. HARRISON, EDWARD, Remarks on the Ineffective State of the Practice of Physic in Great Britain ...' London, R. Bickerstaff, 1806, pp. 12-14, 38-39.

36. Holman, C., Desmond, L. E., and Avelnng, J. H., 'The registration of midwives', Brit. med. J., 1874, i, 186-87.

37. Humphreys, F. R., 'The history of the Act for the Registration of Midwives', Nurs. Times, 1906, 2, 116-17, 199-201, 218-21.

38. KerR, J. M. M., Johnstone, R. W., and PhIllips, M. H. (eds.), Historical Review of British Obstetrics and Gynaecology, 1800-1950, Edinburgh, E. \& S. Livingstone, 1954, pp. 4-5, 278, 332-34.

39. LOWNDES, F. W., 'The registration of midwives', Brit. med. J., 1874, i, 159.

40. McClnntock, A. H. (ed.), Smellie's Treatise on the Theory and Practice of Midwifery, London, New Sydenham Society, 1876, 1, 430-32; 2, 322-24.

41. Mengert, W. F., 'The origin of the male midwife', Ann. med. Hist., 1932, n.s., 4, 453-65.

42. Peachey, G. C., 'Note upon the provision for lying-in women in London up to the middle of the eighteenth century', Proc. $R$. Soc. Med., 1924, 17, 72-76.

43. PhILlimore, Robert, The Ecclesiastical Law of the Church of England, London, Henry Sweet, 1873, 2, pp. 1963, 2060-61.

44. [Proprietas, pseud.], An Address to the Public on the Propriety of Midwives, Instead of Surgeons, Practising Midwifery, London, Longman, Rees, 1826, pp. 1-16.

45. Pugh, Benjamin, A Treatise of Midwifery . . . , London, J. Buckland, 1754, p. A2.

46. Routh, C. H. F., 'On Women as Midwives; a Retrospect of the Past', Med. Press Circ., $1891,102,135-37$.

47. Ryan, MichakL, A Manual on Midwifery . . . , London, Longman, 1828, p. 4.

48. Idem., A Manual of Medical Jurisprudence . . ., London, Renshaw \& Rush, 1831, p. 95.

49. SHARP, JANE, The Midwives Book ..., London. Simon Miller, 1671.

50. Siebold, E. G. J. de, Essai d'une Histoire de l'O bstétricie, Paris, G. Steinhil, 1891, p. 315.

51. Singer, Charles, and Underwood, E. A., A Short History of Medicine, London and New York, Oxford University Press, 1962, p. 227.

52. SPENCER, H. R., The History of British Midwifery from 1650 to 1800 . . . , London, John Bale, Sons, \& Danielsson, 1927, pp. 134, 145-49, 175-76.

53. [Tyson, Ruchard], An Address to the College of Physicians. . . , , London, M. Cooper, 1747 , p. 16.

54. Van Blarcom, C. C., The Midwife in England ..., New York, 1913, pp. 28-34.

55. WeAtherIIL, J., 'Remarks on the employment of female midwives, and on the mode of executing the duties of the coronership at Liverpool', Lancet, 1831, ii, 207-9.

56. WHITE, ROBERT, 'Installation of a midwife', Notes and Queries, 1901, 9th ser., 7, 352.

57. WIILOCK, J. W., The Laws Relating to the Medical Profession. . , , London, J. \& W. T. Clarke, 1830, p. 74. 